\title{
Methanolobus zinderi sp. nov., a methylotrophic methanogen isolated from a deep subsurface coal seam
}

Correspondence James G. Ferry jgf3@psu.edu

\author{
Sebastian N. Doerfert, ${ }^{1} \dagger$ Matthew Reichlen, ${ }^{1} \dagger$ Prabha lyer, ${ }^{2}$ Mingyu Wang ${ }^{1}$ \\ and James G. Ferry ${ }^{1}$ \\ ${ }^{1}$ Department of Biochemistry and Molecular Biology, Pennsylvania State University, University Park, \\ PA 16802, USA \\ 2J. Craig Venter Institute, Rockville, MD 20850, USA
}

Deep subsurface coal deposits are habitats with potential for anaerobic methanogenic consortia that convert coal to methane within abundant water-filled natural fractures called cleats. Stable carbon isotope analyses from Permian coal beds in Australia (Smith \& Pallasser, 1996) and Wilcox coal beds in northern Louisiana, USA (McIntosh et al., 2007), indicate that a portion of the coal bed methane $(\mathrm{CBM})$ is biological in origin. Sequences of $16 \mathrm{~S}$ rRNA genes obtained from the water of a coal seam in northern Japan, located between 843 and $907 \mathrm{~m}$ below the surface, indicated the presence of methanogenic species belonging to the genera Methanoculleus and Methanolobus (Shimizu et al., 2007). Further, unidentified microbial cells have been observed in water from a coal seam in northern Louisiana (Warwick \& MacIntosh, 2007). However, methane-producing isolates from coal beds have yet to be reported. Here we describe the characteristics of strain $\mathrm{SD}^{\mathrm{T}}$, a methane-producing species isolated from water from a northern Louisiana coal seam.

†These authors contributed equally to this work.

Abbreviation: CBM, coal bed methane.

The GenBank/EMBL/DDBJ accession numbers for the 16S rRNA and mcrA gene sequences of Methanolobus zinderi sp. nov. $\mathrm{SD} 1^{\top}$ are EU711413 ${ }^{\top}$ and EU715818 ${ }^{\top}$, respectively.

Graphs showing the effects of temperature, $\mathrm{Na}^{+}, \mathrm{Mg}^{2+}$ and $\mathrm{pH}$ on the growth of strain $\mathrm{SD} 1^{\top}$ are available with the online version of this paper.
Strain $\mathrm{SD} 1^{\mathrm{T}}$ was isolated from a sample of water obtained from a Wilcox coal seam via a CBM well located approximately 40 miles south of Monroe, LA, USA. The sample was taken at the well head in sterile glass jars filled to the top and then sealed to exclude air before transport to the laboratory. The coal seam is situated $926 \mathrm{~m}$ below the surface where the temperature is $51{ }^{\circ} \mathrm{C}$ and the associated water has a pH of 7.8 and contains $26 \mathrm{mM} \mathrm{Mg}^{2+}$ and $0.87 \mathrm{M} \mathrm{Na}^{+}$.

An anaerobic chamber (Coy Manufacturing) was used for isolation and the Hungate method (Hungate, 1969) with modifications (Miller \& Wolin, 1974, Sowers et al., 1984) was used for enrichment cultures and growth studies. The high-salt minimal medium was as described by Sowers et al. (1993) with the following substrates where indicated: $250 \mathrm{mM}$ methanol, $100 \mathrm{mM}$ trimethylamine, $100 \mathrm{mM}$ dimethylamine, $100 \mathrm{mM}$ monomethylamine, $100 \mathrm{mM}$ sodium acetate or $160 \mathrm{kPa} \mathrm{H} / \mathrm{CO}_{2}(80: 20)$ headspace gas mixture. The enrichment medium was high-salt minimal medium containing $250 \mathrm{mM}$ methanol and a head space of $\mathrm{N}_{2} / \mathrm{CO}_{2} / \mathrm{H}_{2}$ (75:20:5). The specific growth rate was determined by measuring the absorbance of cultures at $600 \mathrm{~nm}$. Growth as a function of $\mathrm{pH}$ was determined with high-salt minimal media containing $250 \mathrm{mM}$ methanol with the indicated $\mathrm{pH}$ range obtained by adjusting the ratio of $\mathrm{CO}_{2}$ and $\mathrm{N}_{2}$ contained in the head space. 
Growth experiments were performed in anaerobic culture tubes $(16 \times 150 \mathrm{~mm})$ that contained $10 \mathrm{ml}$ high-salt minimal medium with the indicated substrate and a head space of $\mathrm{N}_{2} / \mathrm{CO}_{2}(80: 20)$ unless indicated otherwise. Tubes were sealed with a butyl rubber stopper that was secured with an aluminium crimp collar. Growth was monitored spectrophotometrically at $600 \mathrm{~nm}$ with a Bausch and Lomb Spectronic 20. Headspace gases were quantified by GC as described by Ferry \& Wolfe (1976).

For DNA isolation, stationary phase cells were collected by centrifugation for $5 \mathrm{~min}$ at $6000 \mathrm{~g}$ at $4{ }^{\circ} \mathrm{C}$. Cells were lysed by incubation for $1 \mathrm{~h}$ at $37^{\circ} \mathrm{C}$ in buffer containing $10 \mathrm{mM}$ Tris/HCl (pH 7.5), $1 \mathrm{mM}$ EDTA (pH 8.0), $0.3 \%(\mathrm{w} / \mathrm{v})$ SDS and $1.5 \mu \mathrm{g} \mathrm{ml}^{-1}$ RNase (Roche). Genomic DNA was extracted from the cell lysate using a Purgene Genomic DNA Extraction kit (Gentra Systems) following the manufacturer's guidelines. The DNA was further purified by two rounds of phenol/chloroform extraction/ethanol precipitation to remove all residual proteins.

The $\mathrm{G}+\mathrm{C}$ content of the genomic DNA of strain $\mathrm{CD} 1^{\mathrm{T}}$ was determined by the thermal denaturation method, essentially as described by Mandel \& Marmur (1968). Purified genomic DNA was diluted in standard SSC buffer to an absorbance of 0.4 at $260 \mathrm{~nm}$ and was dialysed overnight against 1000 volumes SSC. The DNA melting temperature was calculated by monitoring the change in absorbance at $260 \mathrm{~nm}$ over increasing temperatures on a spectrophotometer (model 50; Varian Cary) in combination with a Peltier thermostat-equipped accessory and an anaerobic fluorescence cuvette $[2 \mathrm{~mm} \times 1 \mathrm{~cm}$ (path length)] (Starna). Genomic DNA from Escherichia coli $\mathrm{K}-12$ served as a standard.

For phylogenetic analyses, the $16 \mathrm{~S}$ rRNA gene was amplified using the Archaea-specific primer $3 f$ ( $5^{\prime}$ TCCGGTTGATCCTGCCGG-3') and the universal primer 1423r [5'-ACGGN(AT)ACCTTGTTACGAGTT-3'] (McInerney et al., 1995) and an Advantage HF2 PCR kit (BD Biosciences). The amplified PCR product was sequenced directly using an ABI 3100 automated DNA sequencer. The above mentioned PCR primers were utilized for sequencing. The sequence between positions 64 and 1401 was obtained in this fashion. A modified inverse PCR approach was employed to sequence the $5^{\prime}$ and $3^{\prime}$ ends of the 16S rRNA gene. Genomic DNA was cleaved using the blunt cutter PstI and the fragments were self-ligated to form circular molecules. PCR amplification using outward facing primers complementary to the ends of the sequenced portion of the $16 \mathrm{~S}$ rRNA gene above produced two PCR products of $1.2 \mathrm{~kb}$ and $2.2 \mathrm{~kb}$, respectively. The ends of these PCR fragments were sequenced as above using the PCR primers for sequencing. The $2.2 \mathrm{~kb}$ fragment yielded the $5^{\prime}$ and $3^{\prime}$ ends of the $16 \mathrm{~S}$ rRNA gene. A 745 bp segment of the methyl coenzyme M reductase $(m c r A)$ gene was amplified using the primer set ME1[5'-C(AC)ATGCA(AG)AT(ACT)GG(AT)ATGTC-3'] and ME2 [5'-TCAT(GT)GC(AG)TAGTT(AGT)GG(AG)
TAGT-3'] as described previously (Hales \& Winstanley, 1996) and was sequenced directly as described above for the $16 \mathrm{~S}$ rRNA gene.

The sequences of 1332 bases of the 16S rRNA gene and 490 bases of the mcrA gene from various species were aligned using CLUSTAL_X (Thompson et al., 1997). Phylogenetic trees were deduced using the neighbour-joining algorithm (Saitou \& Nei, 1987). Bootstrap values were calculated using the neighbour-joining method and 1000 replicate datasets and re-evaluated using the SEQBOOT, DNAPARS and CONSENSE programs implemented within the PHYLIP package.

\section{Results and Discussion}

Methanogens were enriched using high-salt minimal medium (Sowers et al., 1993) containing $250 \mathrm{mM}$ methanol as the growth substrate. A $5 \mathrm{ml}$ water sample taken from a deep subsurface coal seam was added to $100 \mathrm{ml}$ medium in a $160 \mathrm{ml}$ stoppered serum vial (Miller \& Wolin, 1974) containing a head space of $\mathrm{N}_{2} / \mathrm{CO}_{2} / \mathrm{H}_{2}$ $(75: 20: 5)$ and incubated at $37^{\circ} \mathrm{C}$. After methane production subsided, subcultures were established with a $5 \mathrm{ml}$ inoculum from which isolates were obtained by plating on solid medium containing $2 \%$ Nobel agar (Difco) in an anaerobic chamber (Coy Manufacturing). Plates were incubated in an atmosphere of $\mathrm{N}_{2} / \mathrm{CO}_{2}(80: 20)$ at $37{ }^{\circ} \mathrm{C}$. Cells from plates containing a single colony type were cultured in $10 \mathrm{ml}$ liquid medium under a head space of $\mathrm{N}_{2} / \mathrm{CO}_{2}(80: 20)$ at $37^{\circ} \mathrm{C}$. When methane production subsided, serial dilutions were replated and incubated as described above. An isolated colony, containing cells of uniform morphology, was cultured in the liquid medium as described above and designated strain $\mathrm{SD}^{\mathrm{T}}$.

Colonies on agar plates appeared after 5 days and reached a diameter of $2-3 \mathrm{~mm}$ after 14 days. The opaque colonies were circular, raised with a smooth surface and entire margins, opaque, dark yellow to light brown in colour and dry in texture. Cells were non-motile, irregular coccoids of $0.5-1.0 \mu \mathrm{m}$ in diameter (Fig. 1a, b) that stained Gramnegative. Aggregates were not observed. Thin-section transmission electron microscopy showed features resembling vacuoles (Fig. 1c) and a cell envelope similar to that of other methanogens containing a protein S-layer adjacent to the cell membrane (Fig. 1d). Cell lysis occurred immediately following the addition of SDS (final concentration $0.1 \%$ ) to the growth medium, consistent with the presence of a protein cell wall.

Growth studies were conducted in high-salt minimal medium (Sowers et al., 1993) containing the indicated substrate and a head space of $\mathrm{N}_{2} / \mathrm{CO}_{2}(80: 20)$. Growth was monitored at $600 \mathrm{~nm}$ and methane was detected by GC. Strain $\mathrm{SDI}^{\mathrm{T}}$ grew and produced methane with $250 \mathrm{mM}$ methanol, $100 \mathrm{mM}$ monomethylamine, $100 \mathrm{mM}$ dimethylamine and $100 \mathrm{mM}$ trimethylamine as carbon and energy sources in the absence of $\mathrm{H}_{2}$. Dimethylsulfide $(100 \mathrm{mM})$, acetate $(100 \mathrm{mM})$, formate $(100 \mathrm{mM})$ and $\mathrm{H}_{2 /} \mathrm{CO}_{2}$ $(80: 20)$ were not utilized by strain $\mathrm{SDI}^{\mathrm{T}}$. Although not 

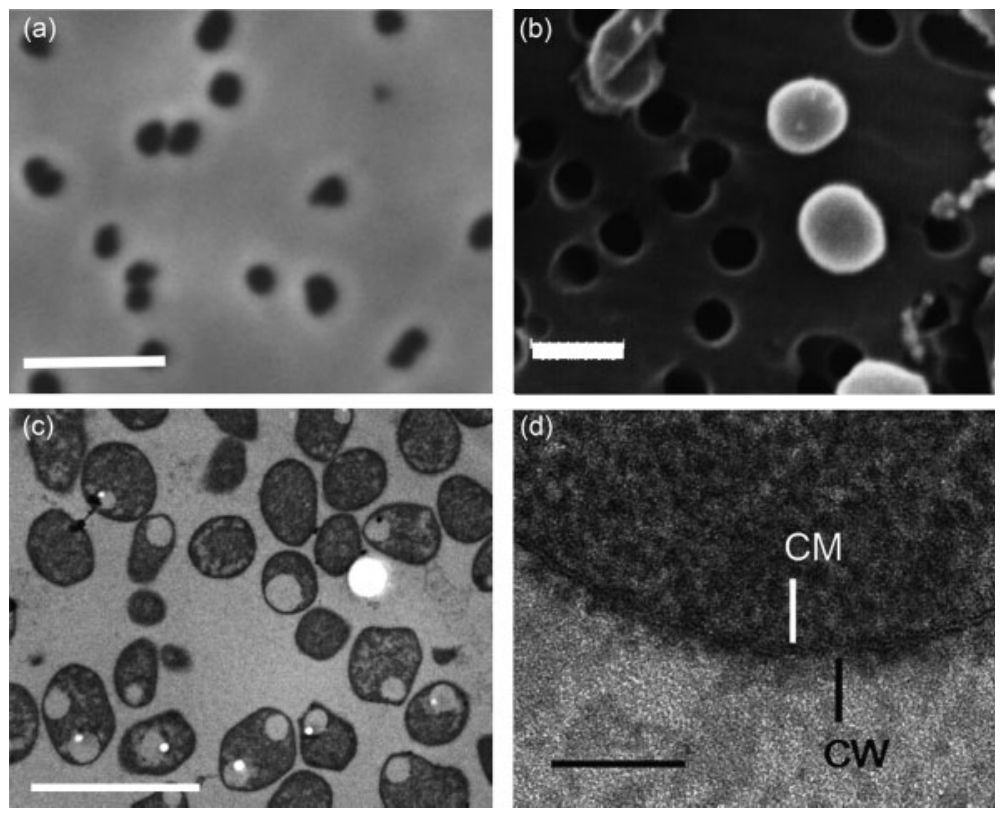

Fig. 1. Morphology of cells of strain $\mathrm{SD}^{\top}$. (a) Phase-contrast micrograph of whole cells. Bar, $5 \mu \mathrm{m}$. (b) Scanning electron micrograph of whole cells. Bar, $0.5 \mu \mathrm{m}$. (c) Thin-section transmission electron micrograph showing vacuole-like structures. Bar, $2 \mu \mathrm{m}$. (d) Thinsection electron micrograph depicting the cell wall $(\mathrm{CW})$ and cytoplasmic membrane (CM). Bar, $0.1 \mu \mathrm{m}$.

required, growth was stimulated by tryptone or acetate. The following growth experiments were conducted in highsalt medium (Sowers et al., 1993) containing $250 \mathrm{mM}$ methanol as the substrate and a head space of $\mathrm{N}_{2} / \mathrm{CO}_{2}$ $(80: 20)$. The temperature range for growth was $25-50{ }^{\circ} \mathrm{C}$, with the maximum rate between 40 and $50{ }^{\circ} \mathrm{C}$ (see Supplementary Fig. S1a in IJSEM Online). Growth was not observed at $55{ }^{\circ} \mathrm{C}$. Sodium chloride was required for growth, was supported at concentrations of 0.05-1.8 M $\mathrm{NaCl}$ and the maximum growth rate occurred at concentrations between 0.2 and $0.6 \mathrm{M} \mathrm{NaCl}$ (Supplementary Fig. S1b in IJSEM Online). Growth was poor with no added $\mathrm{MgCl}_{2}$ (Supplementary Fig. S1c). The optimal conditions for growth were between 10 and $\geqslant 200 \mathrm{mM} \mathrm{MgCl} 2$, with the maximum rate between 100 and $\geqslant 200 \mathrm{mM}$ (Supplementary Fig. S1c). Growth was supported between $\mathrm{pH} 6.0$ and 9.0, with the maximum rate between pH 7.0 and 8.0 (Supplementary Fig. S1d).

The $\mathrm{G}+\mathrm{C}$ content of the genomic DNA of strain was $\mathrm{SD} 1^{\mathrm{T}}$ determined to be $42 \pm 1 \mathrm{~mol} \%$. Comparison of the $16 \mathrm{~S}$ rRNA gene sequence against GenBank using the BLAST search tool revealed that strain $\mathrm{SD}^{\mathrm{T}}$ was most closely related to the methylotrophic species Methanolobus oregonensis (96\%), Methanolobus taylorii (96\%), Methanolobus vulcani (95\%), Methanolobus bombayensis (94\%) and several uncultured clones from a biodegraded oil well (97\%). Other methylotrophic methanogenic species related to strain $\mathrm{SD}^{\mathrm{T}}$ included Methanomethylovorans thermophila (95\%), Methanomethylovorans hollandica strain ZB (94\%), Methanococcoides burtonii (93\%) and Methanohalophilus mahii (93\%). A phylogenetic tree constructed using 16S rRNA gene sequences showed that strain $\mathrm{SD1}^{\mathrm{T}}$ clustered with members of the genus Methanolobus, although bootstrap analysis indicated a clear branching of strain $\mathrm{SD}^{\mathrm{T}}$ from the recognized species of the genus Methanolobus (Fig. 2). This branching occurred in $100 \%$ of trees generated by the neighbourjoining or maximum-parsimony methods. The partial nucleotide sequence of the $m c r A$ gene of strain $\mathrm{SD}^{\mathrm{T}}$ was most closely related to those of Methanolobus bombayensis (94\%), Methanolobus vulcani (93\%), Methanolobus tindarius (92\%) and Methanolobus taylorii (91\%). The deduced partial amino acid sequence of the methylcoenzyme $\mathrm{M}$ methylreductase from strain $\mathrm{SD}^{\mathrm{T}}$ was most similar to that from Methanococcoides burtonii (90\%). Neighbour-joining trees of partial $m c r A$ sequences indicated that the gene sequence of strain $\mathrm{SD} 1^{\mathrm{T}}$ was closest to that of Methanolobus taylorii and clustered with other sequences from species of the genus Methanolobus (Fig. 2). However, it was clearly separated from other species of the genus Methanolobus with the branch occurring in $87 \%$ of all trees.

The results of DNA distance matrix analyses of the 16S rRNA and partial $m c r A$ gene sequences suggested that strain $\mathrm{SD1}^{\mathrm{T}}$ was most closely related to organisms in the genus Methanolobus. Springer et al. (1995) compared 16S rRNA and mcrA gene sequence distances between members of the same genus or different genera within the family Methanosarcinaceae and found 16S rRNA gene distances between members of the same genus to be $0.0214 \pm 0.0065$, whereas distances between members of different genera were $0.0807 \pm 0.0096$. Although these standards did not immediately suggest an unequivocal genus assignment for strain $\mathrm{SD}^{\mathrm{T}}$, the novel strain was closely related to members of the genus Methanolobus with a 16S rRNA gene sequence distance of $0.0351 \pm 0.0037$. Similarly, Springer et al. (1995) found that mcrA gene distances within a given genus were $0.0937 \pm 0.0313$, while distances 
(a)

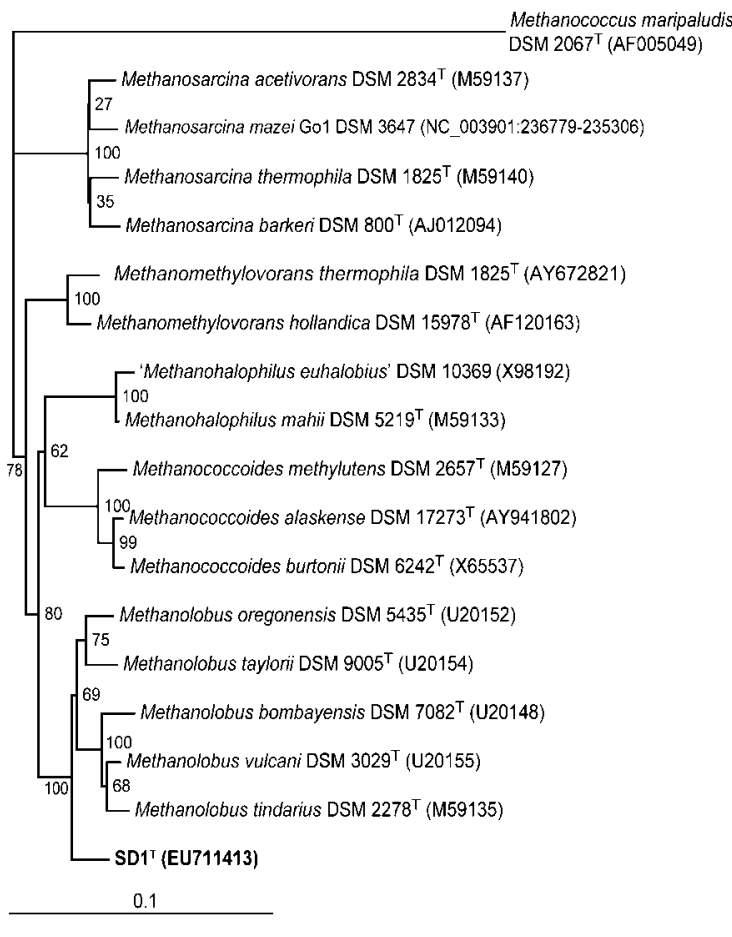

(b)

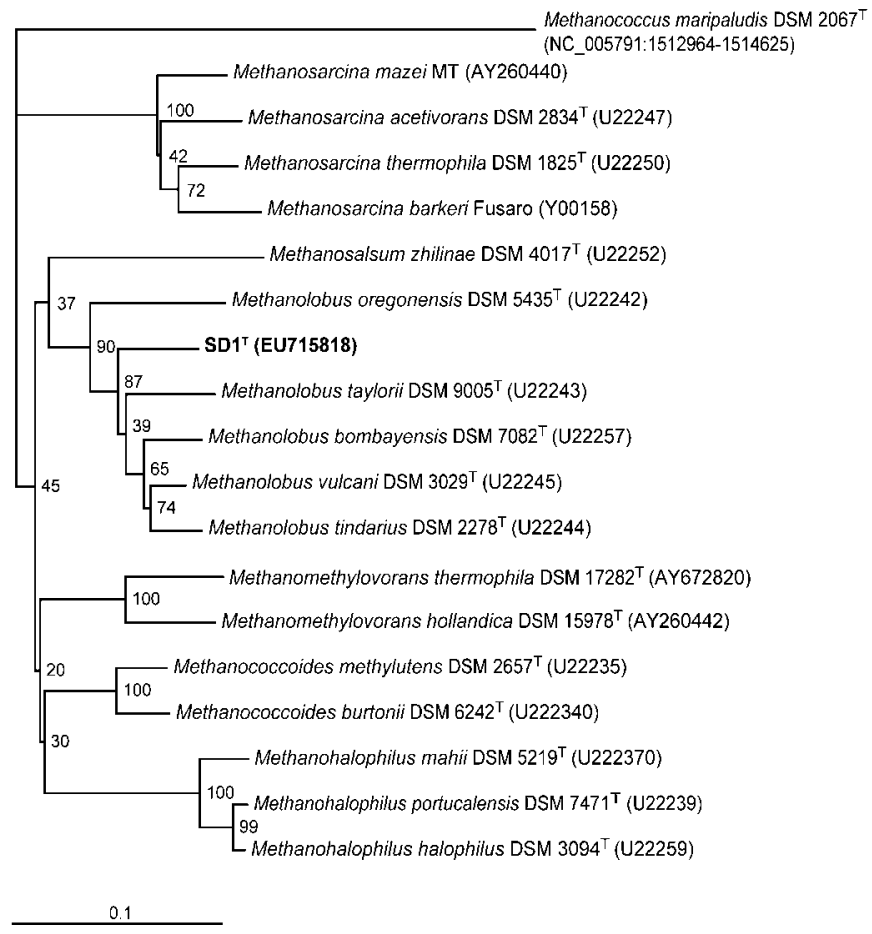

Fig. 2. Phylogenetic trees of $16 \mathrm{~S}$ rRNA (a) and $\operatorname{mcr} A$ (b) gene sequences showing the relationship between strain SD $1^{\top}$ and members of the genera Methanosarcina, Methanomethylovorans, Methanohalophilus, Methanococcoides and Methanolobus, constructed using the neighbour-joining algorithm. The sequences were obtained from GenBank and accession numbers are shown in parentheses. Bars, 0.1 substitutions per nucleotide position.

between genera were $0.245 \pm 0.038$. Applying these standards, it can be seen that strain $\mathrm{SD}^{\mathrm{T}}$ clearly represents a novel species.

Analyses of $16 \mathrm{~S}$ rRNA genes suggest that a diversity of novel methanogens are present in a variety of deep subsurface environments which include faults (Moser et al., 2005), thermal aquifers (Kimura et al., 2005) rock aquifers (Chapelle et al., 2002, Kotelnikova et al., 1998), shales (Takai et al., 2003), petroleum deposits (Cheng et al., 2007, Grabowski et al., 2005, Orphan et al., 2000), methane gas fields (Mochimaru et al., 2007a, b) and coal beds (Shimizu et al., 2007). However, relatively few methanogens have been isolated from these environments and none have been isolated from coal beds. A better understanding of the microbiology of deep subsurface environments is essential to grasp the extent of the Earth's prokaryotic diversity and share of Earth's living protoplasm. The microbiology of coal beds contributes to this understanding and has the added benefit of enabling on-going efforts for the development of processes for microbial enhancement of CBM. Indeed, it is estimated that an increase of $16 \%$ in CBM reserves could be generated by the microbial conversion of only $0.01 \%$ of US coal (Scott, 1999). Furthermore, it is anticipated that the estimated $10^{14} \mathrm{~m}^{3}$ CBM present in deep coal seams worldwide will contribute substantially to future energy sources (Shimada, 1995).
Although several species of methanogens have been isolated from oilfields (Belyaev et al., 1983; Cheng et al., 2007; Ni \& Boone, 1991; Nilsen \& Torsvik, 1996; Ollivier et al., 1997), isolates from methane gas fields or methaneproducing coal beds have not been reported. The temperature, $\mathrm{pH}$ and salinity of the sampled coal water coincided with optimal conditions for growth of strain $\mathrm{SD}^{\mathrm{T}}$, indicating that this strain is well adapted to its environment. The results provide direct microbiological evidence supporting the 16S rRNA gene sequence, isotopic and chemical analyses (McIntosh et al., 2007; Scott, 1999; Shimizu et al., 2007) that suggest that biogenic methane is produced in deep subsurface coal beds by anaerobic microbial consortia.

The results presented here are an important first step in defining the in situ microbial populations and processes necessary to develop methods for the microbial enhancement of CBM. The methylotrophic substrates used by strain $\mathrm{SD} 1^{\mathrm{T}}$ are characteristic of the genus Methanolobus and indicate that one-carbon compounds derived from coal, by either biogenic or thermogenic processes, are potentially important precursors to biogenic CBM. This proposal is supported by $16 \mathrm{~S}$ rRNA gene sequences obtained from deep coal bed water in Japan that indicated a major presence of uncultured species of the genus Methanolobus (Shimizu et al., 2007). 


\section{Description of Methanolobus zinderi sp. nov.}

Methanolobus zinderi (zin'der.i. N.L. gen. masc. n. zinderi of Zinder, named in honour of Stephen H. Zinder for his outstanding contributions to our understanding of the microbiology and ecology of methanogenesis).

Cells are irregular coccoids, $1.0-2.0 \mu \mathrm{m}$ in diameter. Cells are lysed by detergents. Gram-negative. Non-motile. Cells grow by forming methane from methanol and methylamines. Cells are unable to grow with $\mathrm{H}_{2} / \mathrm{CO}_{2}$ or acetate. The maximum rate of growth is between $40-50{ }^{\circ} \mathrm{C}, 0.2-$ $0.6 \mathrm{M} \mathrm{NaCl}, 100-\geqslant 200 \mathrm{mM} \mathrm{MgCl}_{2}$ and $\mathrm{pH}$ 7.0-8.0. No organic compounds are required for growth.

The type strain, SD1 ${ }^{\mathrm{T}} \quad\left(=\mathrm{ATCC} \quad \mathrm{BAA}-1601^{\mathrm{T}}=\mathrm{DSM}\right.$ $21339^{\mathrm{T}}$ ), was isolated from a coal seam near Monroe, LA, USA. The $\mathrm{G}+\mathrm{C}$ content of the genomic DNA of the type strain is $42 \pm 1 \mathrm{~mol} \%$.

\section{Acknowledgements}

This work was supported by a grant from the Pennsylvania State University and EnCana. We thank Robert Downey for the collection of water samples and Missy Hazen and Ruth Haldeman for assistance with electron microscopy.

\section{References}

Belyaev, S. S., Wolkin, R., Kenealy, W. R., Deniro, M. J., Epstein, S. \& Zeikus, J. G. (1983). Methanogenic bacteria from the bondyuzhskoe oil field: general characterization and analysis of stable-carbon isotopic fractionation. Appl Environ Microbiol 45, 691-697.

Chapelle, F. H., O'Neill, K., Bradley, P. M., Methe, B. A., Ciufo, S. A., Knobel, L. L. \& Lovley, D. R. (2002). A hydrogen-based subsurface microbial community dominated by methanogens. Nature $415,312-$ 315.

Cheng, L., Qiu, T. L., Yin, X. B., Wu, X. L., Hu, G. Q., Deng, Y. \& Zhang, H. (2007). Methermicoccus shengliensis gen. nov., sp. nov., a thermophilic, methylotrophic methanogen isolated from oil-production water, and proposal of Methermicoccaceae fam. nov. Int J Syst Evol Microbiol 57, 2964-2969.

Ferry, J. G. \& Wolfe, R. S. (1976). Anaerobic degradation of benzoate to methane by a microbial consortium. Arch Microbiol 107, 33-40.

Grabowski, A., Nercessian, O., Fayolle, F., Blanchet, D. \& Jeanthon, C. (2005). Microbial diversity in production waters of a low-temperature biodegraded oil reservoir. FEMS Microbiol Ecol 54, 427-443.

Hales, B. A. \& Winstanley, C. (1996). Sequencing of (dA:dT) cloned mixed PCR products from microbial populations. Methods Mol Biol 65, 209-218.

Hungate, R. E. (1969). A roll tube method for cultivation of strict anaerobes. Methods Microbiol 3B, 117-132.

Kimura, H., Sugihara, M., Yamamoto, H., Patel, B. K., Kato, K. \& Hanada, S. (2005). Microbial community in a geothermal aquifer associated with the subsurface of the Great Artesian Basin, Australia. Extremophiles 9, 407-414.

Kotelnikova, S., Macario, A. J. \& Pedersen, K. (1998). Methanobacterium subterraneum sp. nov., a new alkaliphilic, eurythermic and halotolerant methanogen isolated from deep granitic groundwater. Int J Syst Bacteriol 48, 357-367.
Mandel, M. \& Marmur, J. (1968). Use of ultraviolet absorbancetemperature profile for determining the guanine plus cytosine content of DNA. Methods Enzymol 12B, 195-206.

Mclnerney, J. O., Wilkinson, M., Patching, J. W., Embley, T. M. \& Powell, R. (1995). Recovery and phylogenetic analysis of novel archaeal rRNA sequences from a deep-sea deposit feeder. Appl Environ Microbiol 61, 1646-1648.

Mclntosh, J. C., Warwick, P. D., Martini, A. M. \& Osborn, S. G. (2007). Coupled hydrology and biogeochemistry of Paleocene-Eocene coal beds, northern Gulf of Mexico, abstract. In Geological Society of America Abstracts with Programs, 257.

Miller, T. L. \& Wolin, M. J. (1974). A serum bottle modification of the Hungate technique for cultivating obligate anaerobes. Appl Microbiol 27, 985-987.

Mochimaru, H., Uchiyama, H., Yoshioka, H., Imachi, H., Hoaki, T., Tamaki, H., Nakamura, K., Sekiguchi, Y. \& Kamagata, Y. (2007a). Methanogen diversity in deep subsurface gas-associated water at the Minami-Kanto gas field in Japan. Geomicrobiol J 24, 93-100.

Mochimaru, H., Yoshioka, H., Tamaki, H., Nakamura, K., Kaneko, N., Sakata, S., Imachi, H., Sekiguchi, Y., Uchiyama, H. \& Kamagata, Y. (2007b). Microbial diversity and methanogenic potential in a high temperature natural gas field in Japan. Extremophiles 11, 453-461.

Moser, D. P., Gihring, T. M., Brockman, F. J., Fredrickson, J. K., Balkwill, D. L., Dollhopf, M. E., Lollar, B. S., Pratt, L. M., Boice, E. \& other authors (2005). Desulfotomaculum and Methanobacterium spp. dominate a 4- to 5-kilometer-deep fault. Appl Environ Microbiol 71, 8773-8783.

Ni, S. S. \& Boone, D. R. (1991). Isolation and characterization of a dimethyl sulfide-degrading methanogen, Methanolobus siciliae HI350, from an oil well, characterization of $M$. siciliae T4/MT, and emendation of M. siciliae. Int J Syst Bacteriol 41, 410-416.

Nilsen, R. K. \& Torsvik, T. (1996). Methanococcus thermolithotrophicus isolated from North Sea oil field reservoir water. Appl Environ Microbiol 62, 728-731.

Ollivier, B., Cayol, J. L., Patel, B. K., Magot, M., Fardeau, M. L. \& Garcia, J. L. (1997). Methanoplanus petrolearius sp. nov., a novel methanogenic bacterium from an oil-producing well. FEMS Microbiol Lett 147, 51-56.

Orphan, V. J., Taylor, L. T., Hafenbradl, D. \& Delong, E. F. (2000). Culture-dependent and culture-independent characterization of microbial assemblages associated with high-temperature petroleum reservoirs. Appl Environ Microbiol 66, 700-711.

Saitou, N. \& Nei, M. (1987). The neighbor-joining method: a new method for reconstructing phylogenetic trees. Mol Biol Evol 4, 406425.

Scott, A. R. (1999). Improving coal gas recovery with microbially enhanced coalbed methane. In Coalbed Methane: Scientific, Environmental and Economic Evaluation, pp. 89-110. Edited by M. Mastalerz, M. Glikson \& S. D. Golding. Dordrecht: Kluwer.

Shimada, M. (1995). State of the art of coalbed methane development. J Min Mater Process Inst Jpn 111, 135-143.

Shimizu, S., Akiyama, M., Naganuma, T., Fujioka, M., Nako, M. \& Ishijima, Y. (2007). Molecular characterization of microbial communities in deep coal seam groundwater of northern Japan. Geobiology 5, 423-433.

Smith, J. W. \& Pallasser, R. J. (1996). Microbial origin of Australian coalbed methane. Am Assoc Pet Geol Bull 80, 891-897.

Sowers, K. R., Baron, S. F. \& Ferry, J. G. (1984). Methanosarcina acetivorans $\mathrm{sp}$. nov., an acetotrophic methane-producing bacterium isolated from marine sediments. Appl Environ Microbiol 47, 971-978. 
Sowers, K. R., Boone, J. E. \& Gunsalus, R. P. (1993). Disaggregation of Methanosarcina spp. and growth as single cells at elevated osmolarity. Appl Environ Microbiol 59, 3832-3839.

Springer, E., Sachs, M. S., Woese, C. R. \& Boone, D. R. (1995). Partial gene sequences for the A subunit of methyl-coenzyme $\mathrm{M}$ reductase ( $m c r \mathrm{I})$ as a phylogenetic tool for the family Methanosarcinaceae. Int $J$ Syst Bacteriol 45, 554-559.

Takai, K., Mormile, M. R., McKinley, J. P., Brockman, F. J., Holben, W. E., Kovacik, W. P., Jr \& Fredrickson, J. K. (2003). Shifts in archaeal communities associated with lithological and geochemical variations in subsurface Cretaceous rock. Environ Microbiol 5, 309-320.

Thompson, J. D., Gibson, T. J., Plewniak, F., Jeanmougin, F. \& Higgins, D. G. (1997). The CLUSTAL_X windows interface: flexible strategies for multiple sequence alignment aided by quality analysis tools. Nucleic Acids Res 25, 4876-4882.

Warwick, P. D. \& MacIntosh, J. C. (2007). Microbial origin of Wilcox group gas in northern Louisiana. In Geological Society of America Abstracts with Programs, 256. 